\title{
Chlorophyll fluorescence response of Pinus radiata clones to nitrogen and phosphorus supply
}

\author{
Horacio E. Bown ${ }^{1}$, Euan G. Mason ${ }^{2}$, Peter W. Clinton ${ }^{3}$, and Michael S. Watt ${ }^{3}$ \\ ${ }^{1}$ Facultad de Ciencias Forestales, Universidad de Chile, Casilla 9206, Santiago, Chile. \\ ${ }^{2}$ School of Forestry, University of Canterbury, Private Bag 4800, Christchurch, New Zealand \\ ${ }^{3}$ Scion Research, PO Box 29237, Christchurch, New Zealand
}

\begin{abstract}
H.E. Bown, E.G. Mason, P.W. Clinton, and M.S. Watt. 2009. Chlorophyll fluorescence response of Pinus radiata clones to nitrogen and phosphorus supply. Cien. Inv. Agr. 36(3):451-464. Chlorophyll fluorescence responses to a factorial combination of nitrogen (N) and phosphorus (P) supply were measured in five clones of Pinus radiata cultivated in a greenhouse over twenty-four months. Chlorophyll fluorescence measurements were taken at months six ( 5 clones, 182 plants), nine ( 2 clones, 68 plants) and eighteen ( 2 clones, 48 plants). Plant growth in stem diameter, height, leaf area, fascicle mass, length and diameter were found to significantly increase with $\mathrm{N}$ and, to a lesser extent, $\mathrm{P}$ additions; and these values were greatest when both $\mathrm{N}$ and $\mathrm{P}$ were combined. Plant growth and fascicle size also varied significantly across clones and were generally consistent with the genotypic growth responses that were observed in the field. Dark $\left(F_{\mathrm{v}} / F_{\mathrm{m}}\right)$ and light-adapted $\left(\Phi_{\mathrm{PSII}}\right)$ photochemical efficiency of PSII were found to significantly increase with $\mathrm{N}$ and, to a lesser extent, $\mathrm{P}$ addition; and the combined effects of $\mathrm{N}$ and $\mathrm{P}$ exceeded those of the individual contributions. Stern-Volmer nonphotochemical quenching, which relates to the proportion of energy dissipated as heat, did not significantly increase as plants became more $\mathrm{N}$ or $\mathrm{P}$ deficient. Chlorophyll fluorescence variables did not differ between clones. We found positive linear relationships between photosynthetic rates at $360 \mu \mathrm{molmol}^{-1} \mathrm{CO}_{2}$ concentration and $1500 \mu \mathrm{mol}$ photons $\mathrm{m}^{-2} \mathrm{~s}^{-1}$ of irradiance $\left(A_{\text {sat }}\right)$, $F_{\mathrm{v}} / F_{\mathrm{m}}$ and $\Phi_{\mathrm{PSII}}$ and both foliar nitrogen $\left(N_{\mathrm{a}}\right)$ and phosphorus $\left(P_{\mathrm{a}}\right)$ concentration on a leaf area basis when a ratio of $N_{\mathrm{a}} / P_{\mathrm{a}}$ equal to $23 \mathrm{~mol} \cdot \mathrm{mol}^{-1}$ was used to partition $\mathrm{N}$ from $\mathrm{P}$ deficiencies. These relationships were independent of genotype. Chlorophyll fluorescence and gas exchange estimates of electron transport were well correlated under ambient photorespiratory conditions, suggesting that chlorophyll fluorescence variables are a good surrogate for gas exchange measurements in our experimental conditions.
\end{abstract}

Key words: Chlorophyll fluorescence, quantum efficiency of PSII, electron transport, genotype, nutrient limitation.

\section{Introduction}

The efficiency by which light is harvested by photosystem II (PS II) reaction centers of the

Received 12 January 2009. Accepted 29 May 2009. Corresponding author: hbown@uchile.cl electron transport system can be assessed using chlorophyll fluorescence techniques (Genty et al. 1989). PSII is highly sensitive and easily damaged by environmental stresses (Ball et al., 1994; Krause and Weis 1991, Maxwell and Johnson 2000), including extreme temperatures, light, nutrient and water limitations (BolharNordenkampf and Oquist, 1993). Thus, chlorophyll fluorescence is widely used to study plant 
stresses, e.g., to assess frost hardiness in Pinus halepensis (Puertolas et al. 2005), to compare healthy and virus-infected plants of Brassica juncea (Guo et al. 2005), to assess chillingdependent photoinhibition of Eucalyptus nitens (Close and Beadle 2003), to determine sink limitation effects on the photosynthetic performance of Abies balsamea (Lavigne et al. 2001) and to discriminate photoprotection from photodamage in Actinidia deliciosa (Greer 1995).

Chlorophyll is located in the pigment-protein complexes that are embedded in the thylakoid membrane, where excitation energy is funneled into the reaction centers $\left(\mathrm{P}_{680}=\right.$ PSII, $\left.\mathrm{P}_{700}=\mathrm{PSI}\right)$ and converted into chemical energy (NADPH and ATP), which is required to drive the photosynthetic carbon reduction (Calvin) cycle (Schreiber et al. 1994, Seibert 1995, Blankenship, 2002). Light energy absorbed by chlorophyll molecules can be used to drive photosynthesis (photochemistry), be dissipated as heat or be re-emitted as chlorophyll fluorescence (Krause and Weis 1991). As these processes are mutually exclusive, changes in the efficiency of photochemistry and heat dissipation can be determined by measuring chlorophyll fluorescence (Maxwell and Johnson 2000). At room temperature, variable fluorescence originates almost exclusively from PSII. Therefore, fluorescence changes primarily reflect the state of PSII (Schreiber et al. 1994). The ratio of variable to maximum chlorophyll fluorescence $\left(F_{\mathrm{v}} / F_{\mathrm{m}}\right)$ is a relative measure of the maximum efficiency of excitation energy captured when all PS II centers are open. Typical values for this ratio are about 0.80-0.83 for a wide variety of dark-adapted non-stressed $\mathrm{C}_{3}$ plants (Ball et al., 1994; Krause and Weis, 1991). In light-adapted leaves, the quantum efficiency of open PSII centers $\left(\Phi_{\text {PSII }}\right)$ represents the efficiency with which excitation energy captured by the light-harvesting antennae is passed to PSII centers and used for photochemistry (Demmig-Adams et al. 1995). Values of $\Phi_{\mathrm{PSII}}$ can be reduced by non-photochemical processes, mainly through the dissipation of excitation energy as heat before it reaches the PSII reaction centers; this process is termed non-photochemical quenching (Krause and Weis 1991). Xantophyll cycle-dependent energy dissipation has been shown to be the predominant mechanism by which leaves adapt to high irradiance
(Demmig-Adams et al. 1995).

Nitrogen $(\mathrm{N})$ and phosphorus $(\mathrm{P})$ are the most likely nutrients limiting primary producers in terrestrial ecosystems (Aerts and Chapin, 2000), and Pinus radiata D. Don is widely planted in the southern hemisphere (Lewis and Ferguson 1993), and its growth has been shown to be limited by soil $\mathrm{N}$ and $\mathrm{P}$ content (Watt et al. 2005). Several authors have observed increased photochemical efficiencies correlated with high foliage nitrogen (Gough et al., 2004; Niinemets et al., 2001) and phosphorus (Conroy et al., 1986; Conroy et al., 1990; Loustau et al., 1999) supplies in conifers. We are unaware of any study that compares the concurrent effects of $\mathrm{N}$ and $\mathrm{P}$ addition on the photochemical efficiency of PSII. Furthermore, how the regulation of photochemical efficiency may account for differences in growth rate in different genotypes is largely unexplored in woody plants. Therefore, we measured the chlorophyll fluorescence response to the addition of $\mathrm{N}$ and $\mathrm{P}$, either individually or in combination, in P. radiata. We also tested whether clones with contrasting growth patterns exhibit differences in photochemical efficiencies of PSII. Our hypotheses were: i. photochemical efficiency increases with the addition of $\mathrm{N}$ or $\mathrm{P}$ or the combination, ii. non-photochemical quenching decreases with the addition of $\mathrm{N}$ or $\mathrm{P}$ or the combination, iii. faster growing genotypes exhibit greater photochemical efficiencies than slower growing genotypes, iv. a stoichiometric ratio of foliage $\mathrm{N}$ to $\mathrm{P}$ of $23 \mathrm{molmol}^{-1}$ will allow to us separate $\mathrm{N}$ from $\mathrm{P}$ deficiencies, and v. chlorophyll fluorescence parameters may correlate with photosynthetic rates under ambient photorespiratory conditions.

\section{Materials and methods}

\section{Plant material}

Plant material was selected from a greenhouse experiment laid out in a factorial design with five clones of $P$. radiata irrigated with two levels of nitrogen $\left(\mathrm{N}_{0}=1.43\right.$ and $\left.\mathrm{N}_{1}=7.14 \mathrm{molm}^{-3}\right)$ and two levels of phosphorus $\left(\mathrm{P}_{0}=0.084\right.$ and $\mathrm{P}_{1}=0.420 \mathrm{molm}^{-3}$ ) supply. Ingestad (1979) suggested that $\mathrm{N}$ should be provided at concentra- 
tions of $100 \mathrm{ppm}(7.14 \mathrm{mM})$ and $\mathrm{P}$ at $13 \mathrm{ppm}$ (0.420 mM) for optimum growth of Pinus pinaster. These concentrations were chosen as the high-N and high-P supply regimes. The low-N (1.43 mM) and low-P (0.084 mM) supply regimes were chosen as one-fifth of the high- $\mathrm{N}$ and high-P concentrations, respectively. Nitrogen was provided as $\mathrm{NH}_{4} \mathrm{NO}_{3}$ and phosphorus as $\mathrm{KH}_{2} \mathrm{PO}_{4}$. Nutrients other than $\mathrm{N}$ and $\mathrm{P}$ were provided at concentrations of: $0.51 \mathrm{molm}^{-3} \mathrm{~K}$, $0.25 \mathrm{molm}^{-3} \mathrm{Ca}, 0.41 \mathrm{molm}^{-3} \mathrm{Mg}, 0.28 \mathrm{molm}^{-3}$ $\mathrm{S}, 12.53 \mathrm{mmolm}^{-3} \mathrm{Fe}, 0.45 \mathrm{mmolm}^{-3} \mathrm{Zn}, 0.47$ $\mathrm{mmolm}^{-3} \mathrm{Cu}, 7.28 \mathrm{mmolm}^{-3} \mathrm{Mn}, 0.073 \mathrm{mmolm}^{-3}$ Mo, $18.50 \mathrm{mmolm}^{-3} \mathrm{~B}, 0.85 \mathrm{mmolm}^{-3} \mathrm{Cl}$ and $0.13 \mathrm{mmolm}^{-3} \mathrm{Na}$, following Ingestad (1979). Genotypes were selected to represent a gradient in growth rates within a set of 400 genotypes planted in the Purokohukohu Experimental Basin (Beets et al., 2004).

One-year old $P$. radiata cuttings from five clones (Clones A, B, C, D and E in descending order of growth performance) were raised under standard nursery conditions for New Zealand (Menzies et al. 2001) and transplanted to $4.3-\mathrm{L}$ pots containing silica sand during the first year of growth. The roots of all plants were artificially inoculated with spores of Rhizopogon rubescens Tul., and the presence of mycorrhizae was confirmed either by visual inspection of roots or by the presence of fruiting bodies. At the end of the first year, plants were transplanted to $42-\mathrm{L}$ pots and grown for another year. Nutrient treatments were allocated randomly to the plants for 24 months. All plants received 0.5 -L of nutrient solution per week during the first year and double that amount in the second year. All plants were daily supplied with water in the same amount in excess of the requirements; pots were allowed to drain freely. The nutrient solution was always applied after watering. Plants were grown in a thermostatically controlled greenhouse, where the mean $( \pm \mathrm{SE})$ air temperature during the day was $18 \pm 4^{\circ} \mathrm{C}$ and $15 \pm 4^{\circ} \mathrm{C}$ at night.

\section{Foliage characteristics}

Fascicle diameter, length, mass and leaf area were measured in three fascicles per plant following chlorophyll fluorescence measurements.
The leaf area of needles $(s)$ was calculated based on fascicle diameter $(d)$, length $(l)$ and the number of needles per fascicle $(n)$ as: $s=(\pi d$ $+n d) l$ (Turnbull et al. 1998). Foliage samples were oven-dried at $70^{\circ} \mathrm{C}$ until the weight was constant, and then the dry mass was recorded. Samples were chemically analyzed by Veritec Laboratories, Rotorua, New Zealand. Tissue N and $\mathrm{P}$ concentrations were determined using Kjeldahl digestion and colorimetric methods using a Segmented Flow Analyzer (SKALAR Analytical BV, Breda, The Netherlands).

\section{Growth measurements}

Growth in plant diameter, height and crown diameter were measured when plants were six months old. Estimates of leaf area were determined as the product of the leaf mass and the leaf area to mass ratio. Foliage mass from when the plants were six months old was estimated from the following equations for foliage mass, $\mathrm{W}$, (g) at different timepoints was predicted from plant diameter, $\mathrm{D},(\mathrm{mm})$ using the following equations: $\mathrm{W}=0.3879 \mathrm{D}^{1.8842}, \mathrm{r}^{2}=0.99, \mathrm{p}<$ 0.001 , Clone $\mathrm{A} ; \mathrm{W}=0.0380 \mathrm{D}^{2.7338}, \mathrm{r}^{2}=0.98, \mathrm{p}<$ 0.001, Clone $\mathrm{B} ; \mathrm{W}=0.1621 \mathrm{D}^{2.1943}, \mathrm{r}^{2}=0.98, \mathrm{p}<$ 0.001 , Clone $\mathrm{C} ; \mathrm{W}=0.0724 \mathrm{D}^{2.5118}, \mathrm{r}^{2}=0.98, \mathrm{p}<$ 0.001 , Clone $\mathrm{D} ; \mathrm{W}=0.0399 \mathrm{D}^{2.7239}, \mathrm{r}^{2}=0.99, \mathrm{p}<$ 0.001 , Clone E. The growth trends that were observed at six months were consistent with those observed when the plants were nine and eleven months old.

\section{Chlorophyll fluorescence measurements}

Chlorophyll fluorescence responses of $P$. radia$t a$ were measured when plants were 6,9 and 18 months old. Clones to be measured and times at which measurements were taken were chosen to complement a larger trial aimed at assessing how nitrogen storage and remobilization is influenced by the addition of $\mathrm{N}$ and $\mathrm{P}$ and genotype. Only chlorophyll fluorescence results are presented in this study.

All genotypes (A, B, C, D, E) were screened using chlorophyll fluorescence techniques when plants were six months old in order to determine 
the extent to which plants were nutritionally stressed (182 plants). We used a pulse-amplitude modulated fluorometer (Mini-PAM-2000, Heinz-Walz, Effeltrich, Germany) equipped with dark leaf-clips (Model DLC-8, Heinz-Walz) to measure the maximum quantum yield $\left(\mathrm{F}_{\mathrm{v}} / \mathrm{F}_{\mathrm{m}}\right)$ of a dark-adapted foliage sample from each plant. The Mini-PAM-2000 equipped with a leaf-clip holder (Model 2030-B, Heinz-Walz) was also used to determine the quantum efficiency of PSII $\left(\Phi_{\mathrm{PSII}}\right)$ at progressive levels of irradiance of a light-adapted foliage sample from each plant (rapid-light curves). Dark- and light-adapted foliage samples from the same plant were different.

Nine months after the beginning of the experiment, 68 plants from clones $\mathrm{B}$ and $\mathrm{E}$ were moved to a growth cabinet the day before the measurements were undertaken. Plants inside of the growth cabinet (temperature varied between $20-25^{\circ} \mathrm{C}$, while leaf-to-air vapor pressure deficit ranged from 1-1.5 $\mathrm{kPa}$ ) were dark-adapted for $30 \mathrm{~min}$. Maximum quantum yield, followed by rapid-light curves (same as that used when plants were six-months old), were triggered in the same foliage sample to determine the SternVolmer non-photochemical quenching $\left(N_{\mathrm{q}}\right)$. Maximum quantum yield of PSII $\left(\left(F_{\mathrm{v}} / F_{\mathrm{m}}\right)\right.$ was determined as $\left(\left(F_{\mathrm{m}}-F_{\mathrm{o}}\right) / F_{\mathrm{m}}\right)$, where $\mathrm{F}_{\mathrm{o}}$ is the minimum fluorescence and $\mathrm{F}_{\mathrm{m}}$ is the maximum fluorescence of the dark-adapted leaf after a light-saturating pulse of about $8000 \mu \mathrm{molm}$ ${ }^{2} \mathrm{~s}^{-1}$ and $800 \mathrm{~ms}$ duration. Rapid light-response curves were then measured using the light-curve program of the Mini-PAM. Actinic light intensity was increased in eight steps every $30 \mathrm{~s}$ during $4 \mathrm{~min}$. The leaf-clip holder was wrapped with a dark cloth to avoid receiving interference from external irradiance with the actinic light provided by the instrument. The measured irradiance was corrected by a factor of 0.8 to account for the distance between the plane of the leaf and the quantum sensor in the Mini-PAM (Rascher et al. 2000). The effective quantum yield of PSII in the light $\left(\Phi_{\mathrm{PSII}}\right)$ was calculated as $\left(\left(F_{\mathrm{m}},-F\right) /\right.$ $\left.F_{\mathrm{m}}{ }^{\prime}\right)$, where $\mathrm{F}$ and $\mathrm{F}_{\mathrm{m}}$ ' are the steady and maximal fluorescence in the light-adapted sample, respectively (Schreiber et al. 1994). Apparent electron transport rates were calculated as $J=$ $\Phi_{\text {PSII }} \times Q \times 0.84 \times 0.5$, where 0.5 is the assumed fraction of absorbed photon energy partitioned to PSII (Maxwell and Johnson 2000), and 0.84 is an average light absorption coefficient estimated for $37 \mathrm{C}_{3}$ species (Björkman and Demmig 1987). The Stern-Volmer non-photochemical quenching $\left(N_{\mathrm{q}}\right)$ was calculated as $\left(F_{\mathrm{m}} / F_{\mathrm{m}}{ }^{\prime}-1\right)$ (Maxwell and Johnson 2000). The response of the apparent electron transport rate $(J)$ to irradiance $(\mathrm{Q})$ was examined using the model described by Prioul and Chartier (1977): $\theta \mathrm{J}^{2}-\left(\alpha \mathrm{Q}+\mathrm{J}_{\max }\right) \mathrm{J}+\alpha \mathrm{QJ}{ }_{\max }$, where $\theta$ is an index of the $J / Q$ curve convexity $(0 \leq \theta \leq 1), \alpha$ is the initial slope of the J/Q curve and $\mathrm{J}_{\max }$ is the fitted asymptotic maximum value of J. The model fit the data precisely $\left(\mathrm{r}^{2}>0.98, \mathrm{p}\right.$ $<0.001)$ with little apparent bias. Similarly, the response of Stern-Volmer non-photochemical quenching $\left(\mathrm{N}_{\mathrm{q}}\right)$ to irradiance $(\mathrm{Q})$ was examined using a von Bertalanffy type model: $\mathrm{N}_{\mathrm{q}}=\mathrm{a}(1-\mathrm{e}$ -b Q ) ${ }^{\mathrm{c}}$, where a , b and c were fitted parameters.

Eighteen months after the beginning of the experiment, 48 plants from clones $\mathrm{B}$ and $\mathrm{E}$ were concurrently measured for gas exchange and chlorophyll fluorescence using a portable photosynthesis system (Model 6400, Li-Cor, Lincoln, $\mathrm{NE}$ ) equipped with an integrated chlorophyll fluorescence detector (LI-6400-40 leaf chamber, Li-Cor, Lincoln, NE). Plants were shifted from the greenhouse to a thermostatically controlled room maintained at $20^{\circ} \mathrm{C}$ the day before the measurements were taken. The temperature was maintained at $20^{\circ} \mathrm{C}$, while VPD was maintained generally below $1 \mathrm{kPa}$. Foliage enclosed in the gas-exchange chamber was left to equilibrate for $10 \mathrm{~min}$ at $360 \mu \mathrm{molmol}^{-1} \mathrm{CO}_{2}$ concentration, $0.21 \mathrm{molmol}^{-1} \mathrm{O}_{2}$ concentration and $1500 \mu \mathrm{molm}^{-2} \cdot \mathrm{s}^{-1}$ of irradiance before measuring the photosynthetic rate $\left(\mathrm{A}_{\text {sat }}\right)$ and the quantum yield of PSII in the light $\left(\Phi_{\mathrm{PSII}}\right)$.

Electron transport rates estimated using the Mini-Pam and the Li-Cor were different; for example, up to $400 \mu \mathrm{molm}^{-2} \mathrm{~s}^{-1}$ was calculated using the Mini-Pam (within ranges given by Bilger et al., 1995), whereas up to $120 \mu \mathrm{molm}^{-}$ ${ }^{2} \mathrm{~S}^{-1}$ was calculated using the $\mathrm{Li}-\mathrm{Cor}$ (this rate is similar to that calculated using gas exchange measurements). These differences were brought about by differences in the equipment configuration and the fact that the electron transport rates estimated by the $\mathrm{Li}$-Cor refer to the measured needle leaf area, whereas the Mini-Pam provides a default value that is independent of the leaf area of the sample. The rate of electron 
transport based on gas exchange was calculated as: $4\left(A_{\text {sat }}+R_{\mathrm{d}}\right)$, where $\mathrm{A}_{\text {sat }}$ is the rate of photosynthesis at ambient $\mathrm{CO}_{2}$ and $1500 \mu \mathrm{molm}^{-2} \mathrm{~s}^{-1}$ of irradiance, and $R_{d}$ is the rate of day respiration calculated using the Laisk method (von Caemmerer 2000). Briefly, the Laisk method involves measuring $\mathrm{A} / \mathrm{C}_{\mathrm{i}}$ (photosynthesis / internal $\mathrm{CO}_{2}$ concentration) response curves at three levels of low irradiance (e.g., $\mathrm{Q}=50,100$ and $\left.300 \mu \mathrm{molm}^{-2} \mathrm{~s}^{-1}\right)$ for several decreasing values of $\mathrm{C}_{\mathrm{i}}$ (e.g., 200 to $0 \mu \mathrm{molmol}^{-1}$ ). Then, the linear relationships between $A$ and $\mathrm{C}_{\mathrm{i}}$ are fitted, and the point of intersection of the three lines projected onto the $A$ axis is taken as $R_{d}$.

\section{Design and statistical analysis}

The experimental design included four nutrient treatments, three blocks, five genotypes and between eight to ten replicates per treatment (182 plants). The block effect was not significant for all of the variables analyzed and was omitted from the results section. Variables were tested for normality and homogeneity of variance, and transformations were made as necessary to meet the underlying statistical assumptions of the models used. The main and interactive effects of $\mathrm{N}$ and $\mathrm{P}$ supply and genotype on chlorophyll fluorescence, fascicle size and plant growth variables were examined by analysis of variance and covariance. Tukey's least significant difference test was used to distinguish among individual means where applicable with a confidence level of $p \leq 0.05$. Differences in slopes and intercepts between genotypes in the linear relationships between chlorophyll fluorescence variables and foliage nutrient concentration were tested for significance by analysis of covariance. All analyses were made at the plant level with SAS software (SAS Institute, Cary, NC, USA).

\section{Results}

\section{Treatment influences on growth}

Plant growth in diameter, height and leaf area was found to be significantly increased by the addition of $\mathrm{N}$ alone, $\mathrm{N}+\mathrm{P}$ and, to a lesser extent, $\mathrm{P}$ alone $\left(\mathrm{F}_{3,38}>12.1, \mathrm{p}<0.001\right)$. On a growth scale, the clones performed in general as $\mathrm{A} \geq \mathrm{C} \geq \mathrm{D} \geq \mathrm{B} \geq \mathrm{E}$; genotypes $\mathrm{A}$ and $\mathrm{E}$ were always significantly different $\left(\mathrm{F}_{4,38}<3\right.$, $\mathrm{p}<0.032$ ) (Table 1). Fascicle diameter, length and mass conformed to plant growth scaling with the addition of $\mathrm{N}$ and $\mathrm{P}$ individually or in combination $\left(\mathrm{F}_{3,38}>25.8, \mathrm{p}<0.001\right)$; in general these values were greater in those genotypes with greater growth performances $\left(\mathrm{F}_{4,38}>16.8\right.$, $\mathrm{p}<0.001$ ) (Table 1). The average mass per fascicle was two-fold greater in Clone $\mathrm{A}$ than in Clone E (Table 1).

Table 1. Growth of Pinus radiata as read by plant diameter, height, leaf area, fascicle diameter, fascicle length and mass per fascicle across nutrient treatments and clones at month six $(n=182)$.

\begin{tabular}{|c|c|c|c|c|c|c|c|}
\hline & $n$ & $\begin{array}{l}\text { Diameter } \\
\mathrm{Mm}\end{array}$ & $\begin{array}{l}\text { Height } \\
\mathrm{mm}\end{array}$ & $\begin{array}{l}\text { Leaf area } \\
\mathrm{m}^{2}\end{array}$ & $\begin{array}{l}\text { Fascicle } \\
\text { diameter, } \mathrm{mm}\end{array}$ & $\begin{array}{l}\text { Fascicle length } \\
\mathrm{mm}\end{array}$ & $\begin{array}{l}\text { Fascicle mass } \\
\text { mg }\end{array}$ \\
\hline \multicolumn{8}{|l|}{ Treatments $^{1}$} \\
\hline $\mathrm{N}_{0} \mathrm{P}_{0}$ & 46 & $3.1 \pm 0.1 \mathrm{a}^{2}$ & $94 \pm 8 a^{2}$ & $0.17 \pm 0.01 \mathrm{a}^{2}$ & $1.32 \pm 0.03 \mathrm{a}^{2}$ & $89 \pm 2 a^{2}$ & $39 \pm 2 a^{2}$ \\
\hline $\mathrm{N}_{0} \mathrm{P}_{1}$ & 46 & $3.4 \pm 0.1 \mathrm{a}$ & $138 \pm 9 b$ & $0.19 \pm 0.01 \mathrm{a}$ & $1.35 \pm 0.03 \mathrm{a}$ & $97 \pm 2 b$ & $43 \pm 2 \mathrm{a}$ \\
\hline $\mathrm{N}_{1} \mathrm{P}_{0}$ & 44 & $3.8 \pm 0.1 \mathrm{~b}$ & $127 \pm 9 b$ & $0.24 \pm 0.01 \mathrm{~b}$ & $1.59 \pm 0.04 b$ & $109 \pm 3 \mathrm{c}$ & $52 \pm 2 b$ \\
\hline \multicolumn{7}{|l|}{ Clones } & $55 \pm 2 b$ \\
\hline A & 39 & $3.8 \pm 0.2 \mathrm{bc}$ & $154 \pm 14 b$ & $0.27 \pm 0.01 \mathrm{c}$ & $1.67 \pm 0.04 \mathrm{c}$ & $117 \pm 2 \mathrm{c}$ & $60 \pm 2 d$ \\
\hline B & 31 & $4.1 \pm 0.2 \mathrm{c}$ & $113 \pm 12 \mathrm{a}$ & $0.21 \pm 0.02 \mathrm{~b}$ & $1.45 \pm 0.04 \mathrm{~b}$ & $106 \pm 3 b$ & $52 \pm 2 \mathrm{c}$ \\
\hline $\mathrm{C}$ & 37 & $3.8 \pm 0.1 \mathrm{bc}$ & $147 \pm 14 b$ & $0.26 \pm 0.02 \mathrm{c}$ & $1.45 \pm 0.03 \mathrm{~b}$ & $94 \pm 3 \mathrm{a}$ & $42 \pm 2 b$ \\
\hline $\mathrm{D}$ & 38 & $3.7 \pm 0.2 \mathrm{~b}$ & $144 \pm 9 b$ & $0.23 \pm 0.02 \mathrm{bc}$ & $1.48 \pm 0.05 \mathrm{~b}$ & $104 \pm 3 b$ & $49 \pm 2 \mathrm{c}$ \\
\hline $\mathrm{E}$ & 37 & $3.2 \pm 0.1 \mathrm{a}$ & $113 \pm 8 a$ & $0.17 \pm 0.01 \mathrm{a}$ & $1.30 \pm 0.03 \mathrm{a}$ & $91 \pm 3 \mathrm{a}$ & $32 \pm 1 \mathrm{a}$ \\
\hline \multicolumn{8}{|c|}{ Analysis of variance } \\
\hline Treatments (T) & & $\mathrm{p}<0.001$ & $\mathrm{p}<0.001$ & $\mathrm{p}<0.001$ & $\mathrm{p}<0.001$ & $\mathrm{p}<0.001$ & $\mathrm{p}<0.001$ \\
\hline Clones (C) & & $\mathrm{p}<0.001$ & $\mathrm{p}<0.05$ & $\mathrm{p}<0.001$ & $\mathrm{p}<0.001$ & $\mathrm{p}<0.001$ & $\mathrm{p}<0.001$ \\
\hline $\mathrm{T} \times \mathrm{C}$ & & 0.29 & 0.38 & 0.68 & 0.47 & 0.19 & 0.38 \\
\hline
\end{tabular}

${ }^{1}$ Nutrient treatments comprise two nitrogen supply regimes $\left(\mathrm{N}_{0}=1.43\right.$ and $\left.\mathrm{N}_{1}=7.14 \mathrm{mM}\right)$ and two phosphorus supply regimes $\left(\mathrm{P}_{0}=0.084\right.$ and $\mathrm{P}_{1}=0.420 \mathrm{mM}$ ).

${ }^{2}$ Means, \pm standard deviation, for each treatment and clone followed by the same letter are not statistically significant according to Tukey's test $(p=0.05)$ 
Influence of treatmenton chlorophyllfluorescence variables

Photochemical efficiency of light-adapted leaves $\left(\Phi_{\text {PSII }}\right)$, which measures the proportion of light used in photochemistry (Maxwell and Johnson 2000), was found to decrease with increasing irradiance (Q), with a steeper decrease and significantly lower $\Phi_{\text {PSII }}$ values in the low-N/low-P supply regime than in regimes with greater $\mathrm{N} / \mathrm{P}$ additions $\left(\mathrm{F}_{3,38}=28.4, \mathrm{p}<0.001\right)$ (Figure 1a). Because apparent electron transport rates $(\mathrm{J})$ are directly proportional to the product of $\Phi_{\mathrm{PSII}}$ and
Q, J values scaled with irradiance (Figure $1 b$ ) and reached significantly greater asymptotic $\mathrm{J}$ values $\left(\mathrm{J}_{\max }\right)$ in the high-N/high-P supply regime than in regimes with lower $\mathrm{N} / \mathrm{P}$ additions $\left(\mathrm{F}_{3,38}\right.$ $=63.1, \mathrm{P}<0.001)$ (Table 2, Figure 2b). The initial slope $(\alpha)$ and convexity $(\theta)$, however, of the $\mathrm{J} / \mathrm{Q}$ response fitted to the model described by Prioul and Chartier (1977) was not significantly influenced by nutrient treatment $\left(\mathrm{F}_{3,38}<1.94, \mathrm{p}>\right.$ $0.13)$, clone $\left(\mathrm{F}_{4,38}<1.70, \mathrm{p}>0.17\right)$ or their interaction $\left(\mathrm{F}_{12,38}<1.51, \mathrm{p}>0.16\right)$, being on average $( \pm 1 \mathrm{SE}) 0.258 \pm 0.001 \mathrm{~mol}$ electrons molquanta ${ }^{-1}$ and $0.851 \pm 0.005$ (no units, value between 0 and 1), respectively (data not shown).

Table 2. Apparent maximal rate of electron transport $\left(\mathrm{J}_{\mathrm{max}}\right)$, photochemical efficiency of PSII $\left(\Phi_{\text {PSII }}\right)$ at an irradiance over $2000 \mu \mathrm{mol}$ photons $\mathrm{m}^{-2} \mathrm{~s}^{-1}$, maximal photochemical efficiency of PSII $\left(\mathrm{F}_{v} / \mathrm{F}_{\mathrm{m}}\right)$ of dark-adapted leaves and the ratio of $\Phi_{\text {PSII }}$ to $\mathrm{F}_{\mathrm{v}} / \mathrm{F}_{\mathrm{m}} \times 10^{3}(\mathrm{R})$ across nutrient treatments and Pinus radiata clones at month six $(\mathrm{n}=182)$.

\begin{tabular}{llllll}
\hline & \multicolumn{3}{l}{$J_{\max }$} \\
& $n$ & $\mu \mathrm{mol} \mathrm{m} \mathrm{m}^{-2} \mathrm{~s}^{-1}$ & $\Phi_{\text {PSII }}$ & $F_{\mathrm{v}} / F_{\mathrm{m}}$ & $\mathrm{R}$ \\
\hline Treatments $^{1}$ & & & & \\
$\mathrm{~N}_{0} \mathrm{P}_{0}$ & 46 & $266 \pm 7 \mathrm{a}^{2}$ & $313 \pm 6 \mathrm{a}^{2}$ & $804 \pm 3 \mathrm{a}^{2}$ & $389 \pm 8 \mathrm{a}^{2}$ \\
$\mathrm{~N}_{0} \mathrm{P}_{1}$ & 46 & $289 \pm 6 \mathrm{a}$ & $329 \pm 5 \mathrm{a}$ & $814 \pm 2 \mathrm{~b}$ & $404 \pm 7 \mathrm{a}$ \\
$\mathrm{N}_{1} \mathrm{P}_{0}$ & 44 & $349 \pm 8 \mathrm{~b}$ & $374 \pm 6 \mathrm{~b}$ & $827 \pm 3 \mathrm{c}$ & $453 \pm 7 \mathrm{~b}$ \\
$\mathrm{~N}_{1} \mathrm{P}_{1}$ & 46 & $399 \pm 9 \mathrm{c}$ & $402 \pm 7 \mathrm{c}$ & $837 \pm 2 \mathrm{~d}$ & $480 \pm 9 \mathrm{c}$ \\
Clones & & & & & \\
$\mathrm{A}$ & 39 & $330 \pm 11 \mathrm{a}$ & $354 \pm 10 \mathrm{a}$ & $818 \pm 3 \mathrm{a}$ & $425 \pm 10 \mathrm{a}$ \\
$\mathrm{B}$ & 31 & $318 \pm 14 \mathrm{a}$ & $348 \pm 9 \mathrm{a}$ & $818 \pm 4 \mathrm{a}$ & $427 \pm 12 \mathrm{a}$ \\
$\mathrm{C}$ & 37 & $332 \pm 14 \mathrm{a}$ & $351 \pm 11 \mathrm{a}$ & $825 \pm 3 \mathrm{a}$ & $428 \pm 11 \mathrm{a}$ \\
$\mathrm{D}$ & 37 & $322 \pm 13 \mathrm{a}$ & $358 \pm 8 \mathrm{a}$ & $820 \pm 3 \mathrm{a}$ & $434 \pm 9 \mathrm{a}$ \\
$\mathrm{E}$ & & & & & $442 \pm 10 \mathrm{a}$ \\
Analysis of variance & & $\mathrm{p}<0.001$ & $\mathrm{p}<0.001$ & $\mathrm{p}<0.001$ & $\mathrm{p}<0.001$ \\
Treatments (T) & & 0.76 & 0.65 & 0.47 & 0.58 \\
Clones (C) & & 0.92 & 0.67 & 0.85 & 0.63 \\
T $\times$ C & & &
\end{tabular}

${ }^{1}$ Nutrient treatments comprise two nitrogen supply regimes $\left(\mathrm{N}_{0}=1.43\right.$ and $\left.\mathrm{N}_{1}=7.14 \mathrm{mM}\right)$ and two phosphorus supply regimes $\left(\mathrm{P}_{0}=0.084\right.$ and $\left.\mathrm{P}_{1}=0.420 \mathrm{mM}\right)$.

${ }^{2}$ Means ( \pm 1 standard deviation) for each treatment and clone followed by the same letter are not statistically significant according to Tukey's test $(p=0.05)$.

The maximum photochemical efficiency of PSII $\left(\mathrm{F}_{\mathrm{v}} / \mathrm{F}_{\mathrm{m}}\right)$, measured when all PSII reaction centers are open in dark-adapted leaves, was found to significantly increase upon the addition of $\mathrm{N}$ and $\mathrm{P}$ individually or in combination $\left(\mathrm{F}_{3,38}=30.97, \mathrm{p}<0.001\right)$ (Table 2, Figure 2a) as a result of a slight reduction in ground fluorescence $\left(\mathrm{F}_{\mathrm{o}}\right)$ and concurrent significant increase in maximum fluorescence $\left(\mathrm{F}_{\mathrm{m}}\right)$ as nutrient supply increased (data not shown). The range in val- ues of $F_{v} / F_{m}$ was relatively narrow ( 0.75 to 0.86 ) compared to light-saturated $\Phi_{\text {PSII }}$ values $(0.20$ to 0.50 ), and the ratio $\Phi_{\mathrm{PSII}}$ to $\mathrm{F}_{\mathrm{v}} / \mathrm{F}_{\mathrm{m}}(\mathrm{R})$ was significantly greater in the high-N/high $\mathrm{P}$ supply regime than in regimes with lower N/P additions $\left(F_{3,38}=24.9, p<0.001\right)$ (Table 2), suggesting that not only photochemical efficiency but also the proportion of reaction centers that are open in the light increases with nutrient supply (Table 2). Chlorophyll fluorescence variables did not significantly differ between clones $\left(\mathrm{F}_{4,38}<0.90\right.$, 


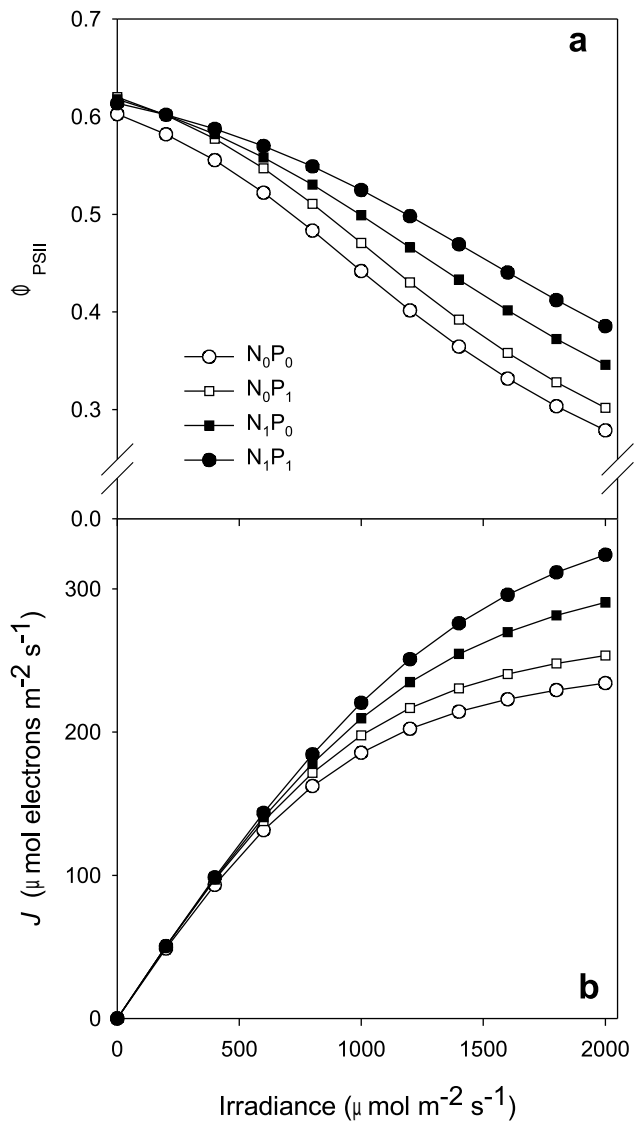

Figure 1. Fitted values of (a) photochemical efficiency of PSII open reaction centers $\left(\Phi_{\mathrm{PSII}}\right)$ and (b) apparent electron transport rate $(\mathrm{J})$ to irradiance $(\mathrm{Q})$ for Pinus radiata given $\mathrm{N}$ and $\mathrm{P}$, individually or in combination. Nutrient treatments comprise two nitrogen supply regimes $\left(\mathrm{N}_{0}=\right.$ $1.43 \mathrm{mM}$ and $\mathrm{N}_{1}=7.14 \mathrm{mM}$ ) and two phosphorus supply regimes $\left(\mathrm{P}_{0}=0.084 \mathrm{mM}\right.$ and $\left.\mathrm{P}_{1}=0.420 \mathrm{mM}\right)$. Symbols: $\mathrm{O}=\mathrm{N}_{0} \mathrm{P}_{0} ; \square=\mathrm{N}_{0} \mathrm{P}_{1} ; \boldsymbol{\square}=\mathrm{N}_{1} \mathrm{P}_{0}$ and $\bullet=\mathrm{N}_{1} \mathrm{P}_{1}$. The $\Phi_{\mathrm{PSII}} / \mathrm{Q}$ and $\mathrm{J} / \mathrm{Q}$ curves do not differ between clones. The model of Prioul and Chartier (1977) was fit to the J/Q response: $\theta \mathbf{J}^{2}-\left(\alpha Q+J_{\max }\right) \mathbf{J}+\alpha Q J_{\max }$, where $\theta$ is an index of the $J / Q$ curve convexity $(0 \leq \theta \leq 1), \alpha$ is the initial slope of the $\mathrm{J} / \mathrm{Q}$ curve and $\mathrm{J}_{\max }$ is the fitted asymptotic maximum value of J. Values of $\alpha$ and $\theta$ were found not to be influenced by nutrient treatment or clone, being on average $( \pm 1 \mathrm{SD})$ $0.258 \pm 0.001 \mathrm{~mol}^{\text {electrons mol quanta }}{ }^{-1}$ and $0.85 \pm 0.01$ (no units, value between 0 and 1), respectively. Values of $\mathrm{J}_{\text {max }}$ were found to increase with nutrient supply independent of the clone, being on average ( $\pm 1 \mathrm{SE}) 266 \pm 7,289 \pm 6$, $349 \pm 8$ and $399 \pm 9 \mu \mathrm{molm}^{-2} \mathrm{~s}^{-1}$ electrons for the nutrient treatments $\mathrm{N}_{0} \mathrm{P}_{0}, \mathrm{~N}_{0} \mathrm{P}_{1}, \mathrm{~N}_{1} \mathrm{P}_{0}$ and $\mathrm{N}_{1} \mathrm{P}_{1}$, respectively. Because the measured J values are calculated as $\Phi_{\mathrm{PSII}} \times \mathrm{Q} \times 0.84 \times$ 0.5 , fit $\Phi_{\mathrm{PSII}}$ values are presented as J $/ \mathrm{Q} \times 2.381$.
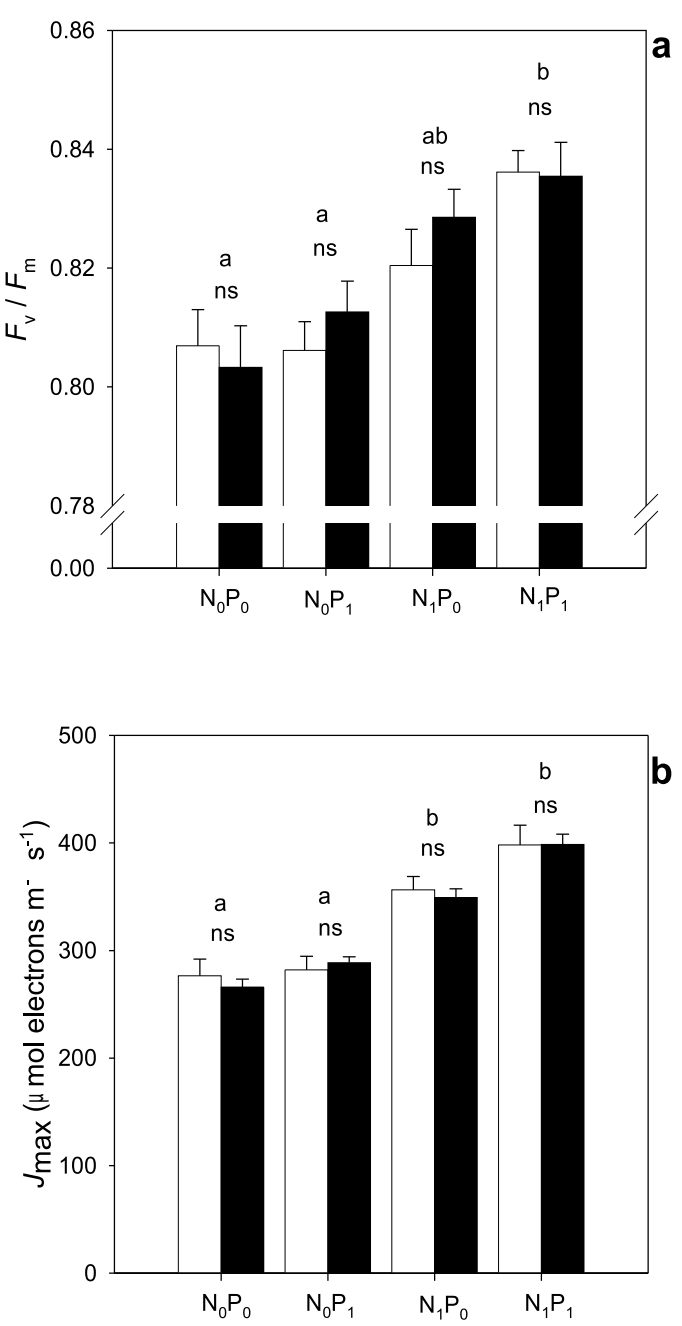

Figure 2. Influence of a factorial combination of nitrogen and phosphorus supply on (a) maximum quantum efficiency of PSII $\left(F_{\mathrm{v}} / F_{\mathrm{m}}\right)$ and (b) maximum apparent electron transport rate $\left(J_{\max }\right)$ of a fast- (Clone A, open bars) and a slow-growing clone (Clone E, closed bars) of Pinus radiata. Treatments comprise a combination of two nitrogen supply regimes $\left(\mathrm{N}_{0}=1.43 \mathrm{mM}\right.$ and $\left.\mathrm{N}_{1}=7.14 \mathrm{mM}\right)$ and two phosphorus supply regimes $\left(P_{0}=0.084 \mathrm{mM}\right.$ and $\left.P_{1}=0.420 \mathrm{mM}\right)$. Values are presented as means $( \pm 1 \mathrm{SE})$ for each treatment and clone. Different letters indicate significant differences between treatment groups at $p<0.05$. Differences between clones are not significant (ns). 
$\mathrm{p}>0.47$ ) (Table 2). The addition of $\mathrm{N}$ individually was found to exert a greater influence on all chlorophyll fluorescence variables studied than the addition of $\mathrm{P}$ individually.

Stern-Volmer non-photochemical quenching $\left(\mathrm{N}_{\mathrm{q}}\right)$, which directly relates to the amount of energy dissipated as heat, was found to significantly increase with increasing irradiance $\left(\mathrm{F}_{3,5}>\right.$ $14, \mathrm{p}<0.007)$. Model parameters a and $\mathrm{c}$ of the von Bertalanffy fit to $\mathrm{N}_{\mathrm{q}}$ versus irradiance did not differ with nutrient treatments $\left(\mathrm{F}_{3,60}<1.19\right.$, $\mathrm{p}>0.32$ ), while parameter $\mathrm{b}$ was significantly higher in the treatment $\mathrm{N}_{1} \mathrm{P}_{0}$ group than in any other treatments $\left(\mathrm{F}_{3,60}=7.31, \mathrm{p}<0.001\right)$ (Figure 3). Model parameters $\mathrm{a}, \mathrm{b}$ and $\mathrm{c}$ did not differ between clones $\left(\mathrm{F}_{1,60}<1.17, \mathrm{p}>0.28\right)$.

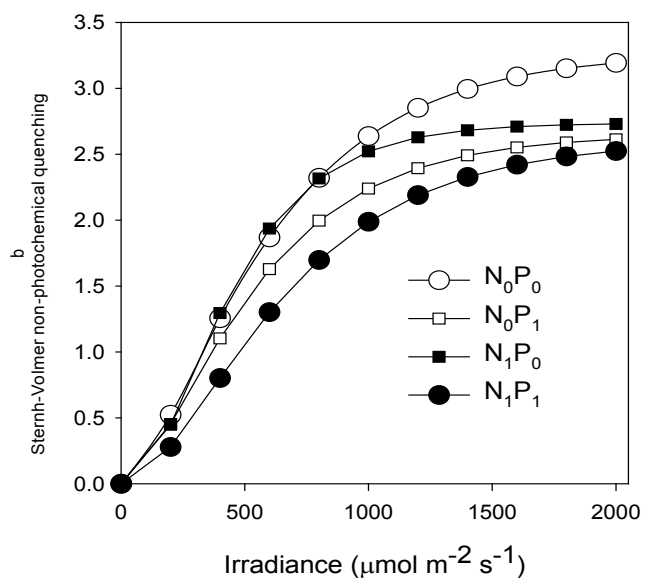

Figure 3. The response of Stern-Volmer non-photochemical quenching $\left(N_{\mathrm{q}}\right)$ to irradiance $(Q)$ as influenced by nutrient treatments at month nine. A von Bertalanffy type model: $N_{\mathrm{q}}=a\left(1-\mathrm{e}^{-b Q}\right)^{c}$ was fitted individually for all plants from clones B and $\mathrm{E}$ ( 68 plants). The model fit the data well $\left(r^{2}>0.98, p<0.001\right)$ with little apparent bias. Only model parameter $b$ was significantly higher in the treatment $\mathrm{N}_{1} \mathrm{P}_{0}$ than in the other treatments. Model parameters $a, b$ and $c$ were not influenced by the clone. Symbols: $\circ=\mathrm{N}_{0} \mathrm{P}_{0}\left[N_{\mathrm{a}}=\right.$ $\left.\left.3.27\left(1-\mathrm{e}^{-0.00216 Q}\right)^{1.74876}\right] ; \square=\mathrm{N}_{0} \mathrm{P}_{1}\left[N_{-}=2.65\left(1-\mathrm{e}^{-0.00245 Q}\right)\right)^{1.86143}\right]$; - $=\mathrm{N}_{1} \mathrm{P}_{0}\left[N_{\mathrm{q}}=2.74\left(1-\mathrm{e}^{-0.00349 Q}\right)^{2.63065}\right]$ and $\bullet=\mathrm{N}_{1} \mathrm{P}_{1}\left[N_{\mathrm{q}}=\right.$ $\left.2.60\left(1-\mathrm{e}^{-0.00211 Q}\right)^{2.09986}\right]$. Presented equations correspond to the average of $16-18$ plants per nutrient treatment.

Influences of treatment on foliage nutrient concentrations

Foliage $\mathrm{N}$ and $\mathrm{P}$ concentrations matched the nutrient treatments at different times of analysis (data shown for month nine only). At the tree level, the observed $\mathrm{N}_{\mathrm{a}}$ ranged almost fourfold from 18 to $75 \mathrm{mmolm}^{-2}$, while $\mathrm{P}_{\mathrm{a}}$ ranged eightfold from 0.7 to $5.6 \mathrm{mmolm}^{-2}$ (Figure 4). The ratio $\mathrm{N}_{\mathrm{a}} / \mathrm{P}_{\mathrm{a}}$ ranged 15-fold from 4.4 to $66.2 \mathrm{molmol}^{-1}$. The values of $\mathrm{N}_{\mathrm{a}} / \mathrm{P}_{\mathrm{a}}$ were not significantly different between treatments $\mathrm{N}_{0} \mathrm{P}_{0}$ and $\mathrm{N}_{1} \mathrm{P}_{1}$ with an average $( \pm 1 \mathrm{SE})$ of $21 \pm 0.6$; however, $\mathrm{N}_{\mathrm{a}} / \mathrm{P}_{\mathrm{a}}$ values for treatments $\mathrm{N}_{0} \mathrm{P}_{1}$ and $\mathrm{N}_{1} \mathrm{P}_{0}$ were significantly different, being on average $9.4 \pm 0.7$ and $50.4 \pm 2.9$, respectively.

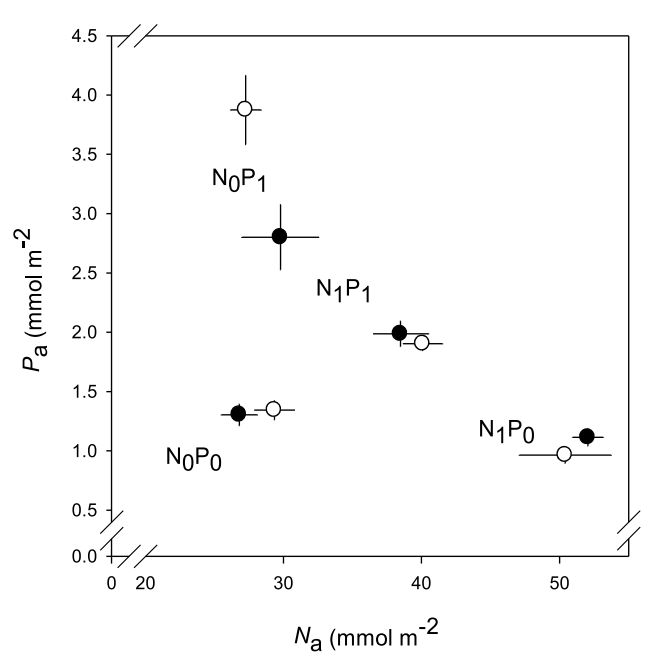

Figure 4. Comparison of foliage nitrogen and phosphorus concentrations in Pinus radiata based on area across nutrient treatments and clones at month nine of the experiment. Treatments were made up as a combination of two levels of nitrogen $\left(\mathrm{N}_{0}=1.43 \mathrm{mM}\right.$ and $\left.\mathrm{N}_{1}=7.14 \mathrm{mM}\right)$ and two levels of phosphorus $\left(\mathrm{P}_{0}=0.084 \mathrm{mM}\right.$ and $\mathrm{P}_{1}=0.420$ $\mathrm{mM})$ supply. Values are presented as means ( $\pm 1 \mathrm{SE})$ for each treatment and clone. Open symbols ( $(\circ)$ represent clone A while closed symbols $(\bullet)$ clone E.

\section{Chlorophyll fluorescence and foliage nutrient concentration}

The relationship between chlorophyll fluorescence variables and foliage nitrogen and phosphorus concentrations followed similar patterns at all times of analysis. The results are presented for month nine only. The ratio of $\mathrm{N}_{\mathrm{a}}$ to $\mathrm{P}_{\mathrm{a}}$ was used to partition the population of chlorophyll fluorescence and gas exchange measurements as nitrogen $\left(\mathrm{N}_{\mathrm{a}} / \mathrm{P}_{\mathrm{a}} \leq 23 \mathrm{molmol}^{-1}\right)$ or phosphorus $\left(\mathrm{N}_{\mathrm{a}} / \mathrm{P}_{\mathrm{a}}>23 \mathrm{molmol}^{-1}\right)$ deficient. The rate of pho- 
tosynthesis at $360 \mu \mathrm{mol} \mathrm{mol}^{-1} \mathrm{CO}_{2}$ concentration and $1500 \mu \mathrm{mol} \cdot \mathrm{m}^{-2} \cdot \mathrm{s}^{-1}$ of irradiance $\left(\mathrm{A}_{\mathrm{sat}}\right), \mathrm{F}_{\mathrm{v}} / \mathrm{F}_{\mathrm{m}}$ and $\mathrm{J}_{\max }$ were strong and linearly related to $\mathrm{N}_{\mathrm{a}}$ $\left(\mathrm{F}_{1,43}>8, \mathrm{p}<0.008\right)$ and $\mathrm{P}_{\mathrm{a}}\left(\mathrm{F}_{1,23}>33, \mathrm{p}<0.001\right)$, except for the relationship between $\mathrm{F}_{\mathrm{v}} / \mathrm{F}_{\mathrm{m}}$ and
$\mathrm{P}_{\mathrm{a}}$, which was non-significant $\left(\mathrm{F}_{3,23}=1.76, \mathrm{p}=\right.$ $0.18)$. Slopes and intercepts of the relationships between $\mathrm{A}_{\text {sat }}, \mathrm{F}_{\mathrm{v}} / \mathrm{F}_{\mathrm{m}}$ and $\mathrm{J}_{\max }$ to either $\mathrm{N}_{\mathrm{a}}$ or $\mathrm{P}_{\mathrm{a}}$ were not significantly different between clones (Figure 5).

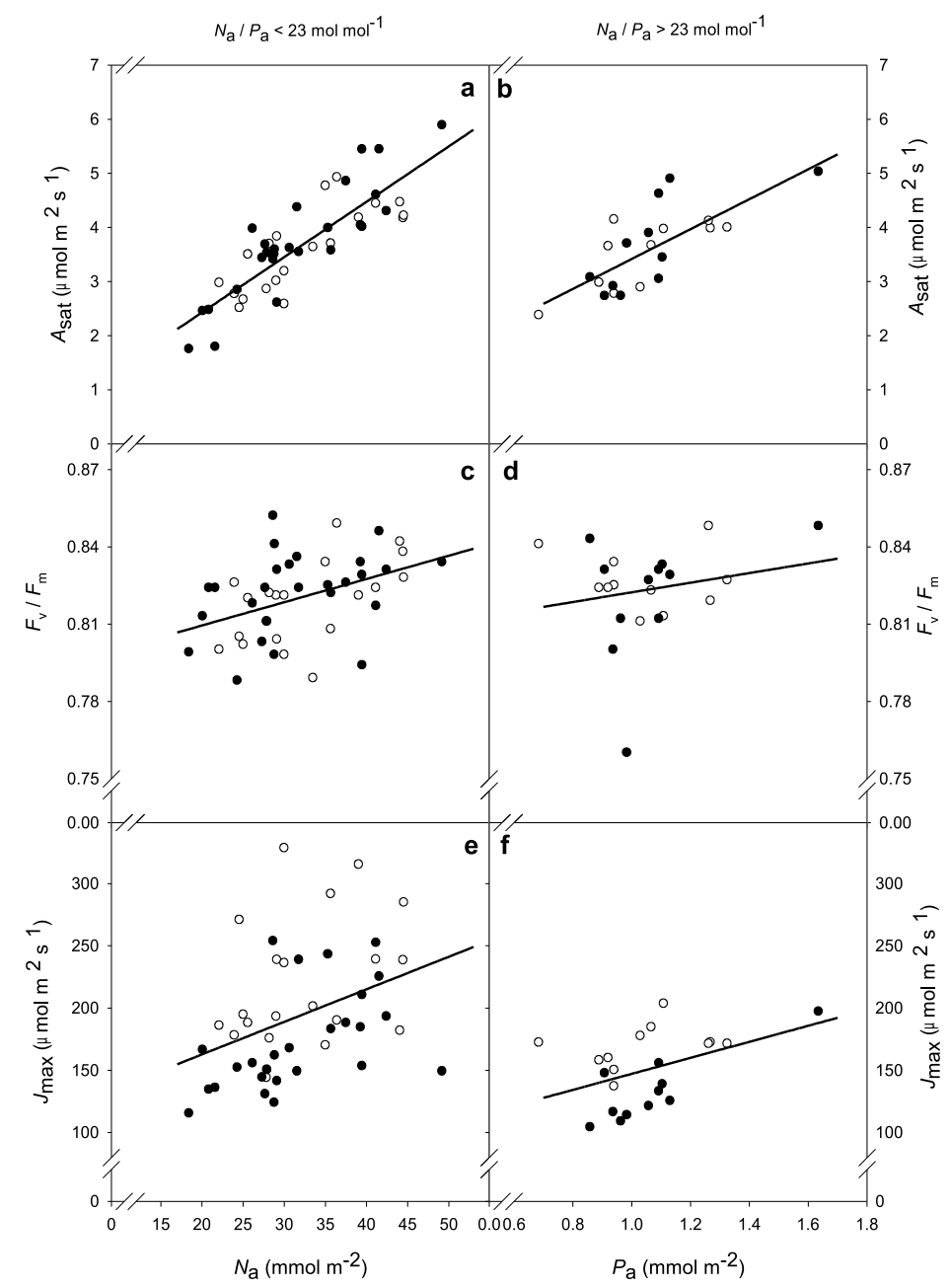

Figure 5. The rate of photosynthesis, $A_{\text {sat }}$, the maximal photochemical efficiency of PSII of dark-adapted leaves, $F_{\mathrm{v}} / F_{\mathrm{m}}$, and the apparent rate of electron transport, $J_{\max }$, against foliage nitrogen $\left(N_{\mathrm{a}}\right)$ and phosphorus $\left(P_{\mathrm{a}}\right)$ concentration on an area basis for Pinus radiata clones B (०) and E $(\bullet)$ at month 9.

\section{Chlorophyll fluorescence and gas exchange}

Chlorophyll fluorescence and gas exchange estimates of electron transport were well correlated $\left(\mathrm{F}_{1,47}=37.8, \mathrm{p}<0.001\right)$; the slopes $\left(\mathrm{F}_{3,40}<1.24\right.$, $\mathrm{p}$ $>0.31)$ and intercepts $\left(\mathrm{F}_{3,40}<1.84, \mathrm{p}>0.15\right)$ of these linear relationships were not influenced by nutrient treatment or clone (Figure 5). This rela- tionship has been described previously by Genty et al. (1989) and von Caemmerer (2000) under non-photorespiratory conditions (elevated $\mathrm{CO}_{2}$ and low 0.01-0.02 $\mathrm{molmol}^{-1} \mathrm{O}_{2}$ concentration) to have very high correlations $\left(r^{2}>0.98\right)$. Our measurements were carried out under normal photorespiratory conditions (ambient $\mathrm{CO}_{2}$ and $\mathrm{O}_{2}$ concentration), and the relationship found was still highly significant (Figure 6). This sug- 
gests that under our experimental conditions, chlorophyll fluorescence variables are a good surrogate for gas exchange measurements.

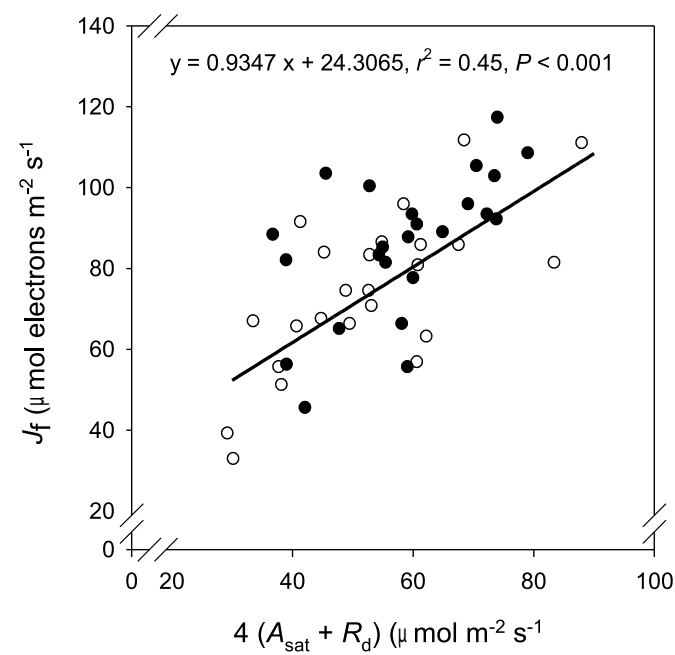

Figure 6. Relationship between the rate of electron transport calculated from measurements of chlorophyll fluorescence $\left(J_{f}\right)$ versus electron transport rates calculated from gas exchange: $4\left(\mathrm{~A}_{\text {sat }}+\mathrm{R}_{\mathrm{d}}\right)$ for Pinus radiata. $\mathrm{A}_{\text {sat }}$ is the rate of photosynthesis at $360 \mu \mathrm{molmol}^{-1} \mathrm{CO}_{2}$ concentration and $1500 \mu \mathrm{molm}^{-2} \mathrm{~s}^{-1}$ of irradiance, and $\mathrm{R}_{\mathrm{d}}$ is the rate of day respiration (both based on projected leaf area), following von Caemmerer (2000). Gas exchange and chlorophyll fluorescence measurements were carried out concurrently on 48 plants of $P$. radiata at $20^{\circ} \mathrm{C}$, ambient $\mathrm{CO}_{2}\left(360 \mu \mathrm{molmol}^{-1}\right)$ and $\mathrm{O}_{2}\left(0.21 \mathrm{molmol}^{-1}\right)$ and an irradiance of $1500 \mu \mathrm{molm}$ ${ }^{2} \mathrm{~s}^{-1}$ in the month 18 of the experiment.

\section{Discussion}

Our data support our first hypothesis that the addition of $\mathrm{N}$ and $\mathrm{P}$, individually or in combination, increases the photochemical efficiency of PSII in dark- and light-adapted leaves of $P$. radiata. We noted significant differences in how $\mathrm{N}$ and $\mathrm{P}$ modify these parameters, however. Nitrogen and, to lesser extent $P$, additions were found to increase the proportion of open PSII reaction centers in the light and increase the efficiency of energy trapping by open PSII centers. Our data clearly show that the individual addition of $\mathrm{N}$ increases the maximal photochemical efficiency of PSII $\left(\mathrm{F}_{\mathrm{v}} / \mathrm{F}_{\mathrm{m}}\right)$ to 2.3 times greater than after the addition of $\mathrm{P}$ alone $\left(\mathrm{F}_{\mathrm{v}} / \mathrm{F}_{\mathrm{m}}\right.$ for $\mathrm{N}_{0} \mathrm{P}_{0}$ was 804 , and increased by $1.2 \%$ for $\mathrm{N}_{0} \mathrm{P}_{1}$ and $2.8 \%$ for $\mathrm{N}_{1} \mathrm{P}_{0}$ ) (Table 2). The values of $\mathrm{J}_{\max }, \Phi_{\mathrm{PSII}}$ and $\mathrm{R}\left(=\Phi_{\text {PSII }} / \mathrm{F}_{\mathrm{v}} / \mathrm{F}_{\mathrm{m}}\right)$ followed the same pattern. Several authors have observed increases in pho- tochemical efficiencies in the presence of higher foliage nitrogen (Gough et al., 2004; Niinemets et al., 2001) and phosphorus (Conroy et al., 1986; Conroy et al., 1990; Loustau et al., 1999) supplies in conifers, but we are unaware of any study comparing the separate and combined effects of $\mathrm{N}$ and $\mathrm{P}$ addition on the photochemical efficiency of PSII.

We found that the second hypothesis, which states that non-photochemical quenching decreases with individual or combined addition of $\mathrm{N}$ and $\mathrm{P}$, to be false in a strict statistical sense, but we believe this hypothesis to be true in a broader physiological sense. We observed high variability in the measurement of this variable, which probably prevented us from finding significant differences between nutrient treatments. Overall, Stern-Volmer non-photochemical quenching tended to decrease (plants dissipated less heat) with the addition of $\mathrm{N}$ and P: model parameter a (asymptote to the $\mathrm{N}_{\mathrm{q}} / \mathrm{Q}$ response curve) was equal to 3.3 in the low-N/ low-P treatment, whereas it was 2.6 in the high-N/high-P supply regime (typical values 0.5-3.5, Maxwell and Johnson, 2000) (Figure 3). The sole addition of $\mathrm{N}$ significantly increases model parameter $\mathrm{b}$ (shape parameter for the $\mathrm{N}_{\mathrm{q}}$ / Q response curve) over all other treatments, making non-photochemical quenching very responsive to increases in irradiance below 800 $\mu \mathrm{mol} \mathrm{m} \mathrm{m}^{-2} \mathrm{~s}^{-1}$ and evening out drastically after this threshold (Figure 3). The activity of PSII is highly regulated by irradiance and the use of ATP and NADPH in the Calvin cycle and other metabolic processes in the chloroplast (Rosenqvist and van Kooten, 2003); therefore, the photochemical efficiency of PSII and the rate of heat dissipation must be adjusted so that the electron transport rates match the capacity of the photosynthetic carbon reduction (Calvin) cycle (Ruban and Horton 1995).

Our data is inconsistent with our third hypothesis, which stated that faster growing genotypes exhibit greater photochemical efficiencies than slower growing genotypes. Only a few studies have reported on the genetic variation in chlorophyll fluorescence traits in forest species. Koehn et al. (2003) observed genetic variation in photochemical quenching $\left(\mathrm{q}_{\mathrm{P}}\right)$ and $\Phi_{\text {PSII }}$ but not in non-photochemical quenching $\left(\mathrm{q}_{\mathrm{N}}\right)$ among 
slash pine families ( $P$. elliottii var. elliottii). In contrast, Marshall et al. (2001) found insignificant differences in maximum photochemical efficiency $\left(\mathrm{F}_{\mathrm{v}} / \mathrm{F}_{\mathrm{m}}\right)$ between tall and short (i.e. height growth traits) open-pollinated families of Pseudotsuga menziesii, Pinus ponderosa and Pinus monticola. In this study, chlorophyll fluorescence variables were not influenced by genotype. Pearcy et al. (1987) points out that environmental variation in resource availability influences photosynthetic responses more strongly than do genetic differences between individuals. Schreiber et al. (1994) and BolharNordenkampft and Oquist (1993) have argued that chlorophyll fluorescence methods may be useful for selecting optimal genotypic performance under different environmental stresses; however, in the particular case of $P$. radiata, the results of our study suggest that screening genotypes for nutritional stresses using chlorophyll fluorescence techniques is not promising.

The fourth hypothesis, suggesting that a stoichiometric ratio of foliage $\mathrm{N}$ to $\mathrm{P}$ of $23 \mathrm{molmol}^{-1}$ allows one to separate $\mathrm{N}$ from $\mathrm{P}$ deficiencies, was found to be true. The range of $\mathrm{N}_{\mathrm{a}}$ and $\mathrm{P}_{\mathrm{a}}$ in the foliage sampled was wide, more than covering the range of low, marginal and satisfactory levels of foliage nitrogen and phosphorus concentrations for $P$. radiata that were proposed by Will (1985) to indicate the nutrient status of plants. In this study, the photochemical efficiency of PSII correlated well with the foliage $\mathrm{N}$ and $\mathrm{P}$ when we used a ratio of $\mathrm{N}_{\mathrm{a}} / \mathrm{P}_{\mathrm{a}}$ equal to $23 \mathrm{molmol}^{-1}$ to separate $\mathrm{N}$ from $\mathrm{P}$ deficiencies (Figure 5). Stoichiometric ratios have been extensively used to measure optimum nutrition levels and explain particular nutrient limitations (Ingestad, 1971, 1979; Ingestad and Lund, 1986). Knecht and Göransonn (2004) argued that the optimum ratio of nitrogen to phosphorus in terrestrial plants is similar for a wide range of species and equal to about 100:10 $\mathrm{gg}^{-1}\left(23 \mathrm{molmol}^{-1}\right)$. Several authors (Reich and Schoettle, 1988; Marschner 1995; Aerts and Chapin, 2000) have suggested that deviations in these levels lead to nitrogen $\left(\mathrm{N}_{\mathrm{a}} / \mathrm{P}_{\mathrm{a}} \leq 23\right)$ or phosphorus $\left(\mathrm{N}_{\mathrm{a}} / \mathrm{P}_{\mathrm{a}}>23\right)$ deficiencies. We found this partitioning approach to give consistent results across all timepoints. Chlorophyll fluorescence variables below a $\mathrm{N}_{\mathrm{a}}$ $/ \mathrm{P}_{\mathrm{a}}$ ratio of $23 \mathrm{molmol}^{-1}$ correlated well with $\mathrm{N}_{\mathrm{a}}$ but not with $\mathrm{P}_{\mathrm{a}}$, while observations above 23 molmol ${ }^{-1}$ scaled positively and linearly with $\mathrm{P}_{\mathrm{a}}$ but not with $\mathrm{N}_{\mathrm{a}}$ in all timepoints.

Fascicle size and plant leaf area scaled with nitrogen and, to a lesser extent, phosphorus supply, with slow growing clones generally exhibiting smaller fascicles and smaller leaf areas than faster growing clones (Table 1). Cookson et al. (2005) argue that leaf development is influenced by genetic, hormonal, nutritional and environmental factors. Fife and Nambiar (1997) argue that $\mathrm{N}$ supply increases leaf mass by developing larger and greater density of needles and observed that needle mass increases with $\mathrm{N}$ supply in P.radiata. Similarly, Niinemets et al. (2001) observed that needles are shorter in an $\mathrm{N}$ and P-poor site compared to a $\mathrm{N}$ and P-rich site in P.sylvestris. Gough et al. (2004) argued that fertilization results in more $\mathrm{C}$ being fixed per unit leaf area, with the additional photo-assimilate being subsequently converted into larger leaf area. Differences in productivity across nutrient treatments can be at least partially explained by greater $\mathrm{C}$ allocation to the leaf area and greater photochemical efficiency in the high-N/high-P nutrient supply regime compared to the lower N/P regime. Differences in growth performances among clones (Table 1) can be attributed at least partially to changes in leaf area and fascicle size but not to photosynthetic performance per unit leaf area.

The fifth hypothesis, which stated that chlorophyll fluorescence parameters correlate well with photosynthetic rates under ambient photorespiratory conditions, was found to be true. Electron transport rates calculated using chlorophyll fluorescence techniques are generally indicative of overall rates of photosynthesis; the advantage of this method is that these rates can be determined almost instantaneously (Maxwell and Johnson, 2000). Genty et al. (1989) showed that under experimental non-photorespiratory conditions $\Phi_{\mathrm{PSII}}$ is well correlated with $\Phi_{\mathrm{CO} 2}\left(\mathrm{r}^{2}\right.$ $=0.99$ ), and we found that this relationship is still highly significant for electron transport $\left(\mathrm{r}^{2}\right.$ $=0.45$ ) at ambient $\mathrm{O}_{2}$ concentrations. Maxwell and Johnson (2000) argue that this relationship breaks down under field conditions, but we suggest that concurrent measurements of chlorophyll fluorescence and gas exchange in a small sample set may provide the means to validate chlorophyll fluorescence observations in the field as a 
measure of photosynthetic performance under ambient photorespiratory conditions.

In conclusion, this paper examined chlorophyll fluorescence responses to nitrogen and phosphorus supply in $P$. radiata clones. This study shows that the addition of $\mathrm{N}$ and, to a lesser extent $\mathrm{P}$, increases the proportion and efficiency of open PS II centers in the light without significantly decreasing heat dissipation. We also found that the effects of nitrogen and phosphorus supply on chlorophyll fluorescence variables are statistically independent and not influenced by genotype. This conclusion applies only to the clones that we tested under the given experimental conditions; some genotypic variation may be expected with respect to nutrient capture and use efficiency under field conditions.

\section{Resumen}

H.E. Bown, E.G. Mason, P.W. Clinton y M.S. Watt. 2009. Respuestas en fluorescencia de la clorofila de clones de Pinus radiata a la adición de nitrógeno y fósforo. Cien. Inv. Agr. 36(3): 451-464. Se evaluaron las respuestas en fluorescencia de la clorofila frente a una combinación factorial de adiciones de nitrógeno $(\mathrm{N})$ y fósforo $(\mathrm{P})$ en cinco clones de Pinus radiata cultivados en un invernadero por 24 meses. Se midió la fluorescencia de la clorofila en tres ocasiones: al sexto mes ( 5 clones, 182 plantas), al noveno mes ( 2 clones, 68 plantas) y al décimo octavo mes ( 2 clones, 48 plantas). El crecimiento en diámetro, altura y área foliar de las plantas, y la masa, longitud y diámetro de los fascículos aumentaron significativamente con adiciones de $\mathrm{N}$ y en menor medida con adiciones de $\mathrm{P}$, y todas estas variables fueron máximas cuando ambos $\mathrm{N}$ y $\mathrm{P}$ se aplicaron en forma combinada. Las variables de crecimiento de las plantas y de tamaño de los fascículos también fueron significativamente influidos por el genotipo los que además fueron generalmente consistentes con las respuestas observadas en los ensayos de campo. La eficiencia fotoquímica del FSII de las muestras de follaje adaptadas a la oscuridad $\left(\mathrm{F}_{\mathrm{v}} / \mathrm{F}_{\mathrm{m}}\right)$ y a la luz $\left(\Phi_{\mathrm{PSII}}\right)$ aumentaron significativamente con adiciones de $\mathrm{N}$ y en menor medida con adiciones de $\mathrm{P}, \mathrm{y}$ los efectos combinados de $\mathrm{N}$ y $\mathrm{P}$ excedieron aquellos de sus contribuciones individuales. El máximo quenching no fotoquímico (Stern-Volmer), el cual es un indicador de la proporción de energía disipada como calor, no aumentó significativamente en la medida que las plantas fueron más deficientes en $\mathrm{N}$ o $\mathrm{P}$. Las variables asociadas a la fluorescencia de la clorofila no difirieron entre los clones. Se encontró relaciones lineales positivas entre las tasa de fotosíntesis medida a $360 \mu \mathrm{mol} \mathrm{mol}^{-1}$ de concentración de $\mathrm{CO}_{2}$ e irradiación de $1500 \mu \mathrm{mol}$ fotones $\mathrm{m}^{-2} \mathrm{~s}^{-1}\left(\mathrm{~A}_{\mathrm{sat}}\right), \mathrm{F}_{\mathrm{v}} / \mathrm{F}_{\mathrm{m}}$ y $\Phi_{\mathrm{PSII}}$ y las concentraciones foliares de nitrógeno $\left(\mathrm{N}_{\mathrm{a}}\right)$ y fósforo $\left(\mathrm{P}_{\mathrm{a}}\right)$ expresadas sobre una base de área foliar cuando se utilizó una razón $\mathrm{N}_{\mathrm{a}} / \mathrm{P}_{\mathrm{a}}$ igual a 23 molmol $^{-1}$ para separar deficiencias de $\mathrm{N}$ de las deficiencias de $\mathrm{P}$. Estas relaciones fueron independientes del genotipo. Las estimaciones de transporte de electrones basadas en fluorescencia de la clorofila e intercambio gaseoso se encontraron bien correlacionadas bajo condiciones ambientales normales de fotorespiración, sugiriendo que las variables asociadas a la fluorescencia de la clorofila fueron un buen estimador de las tasas de fotosíntesis para nuestras condiciones experimentales.

Palabras clave: Eficiencia fotoquímica del FSII, fluorescencia de la clorofila, genotipo, limitaciones nutricionales, transporte de electrones. 


\section{References}

Aerts, R., and F.S.I. Chapin. 2000. The mineral nutrition of wild plants revisited: A re-evaluation of processes and patterns. Advances in Ecological Research. 30:1-5767.

Ball, M.C., J.A. Butterworth, J.S. Roden, R. Christian, and J.J.G. Egerton. 1994. Applications of chlorophyll fluorescence to forest ecology. Australian Journal Plant Physiology. 1994:311-319.

Beets, P.N., G.R. Oliver, M.O. Kimberley, S.H. Pearce, and B. Rodgers 2004. Genetic and soil factors associated with variation in visual magnesium deficiency symptoms in Pinus radiata. Forest Ecology and Management. 189:263-279.

Bilger, W., U. Schreiber, and M. Bock 1995. Determination of the quantum efficiency of photosystem II and of non-photochemical quenching of chlorophyll fluorescence in the field. Oecologia 102:425-432.

Björkman, O., and B. Demmig 1987. Photon yield of $\mathrm{O} 2$ evolution and chlorophyll fluorescence characteristics at $77 \mathrm{~K}$ among vascular plants of diverse origins. Planta. 170:489-504.

Blankenship, R.E. 2002. Photosynthesis: the light reactions. Pages 111-143. In. L. Taiz and E. Zeiger (eds.). Plant Physiology. Sinauer Associates, Inc., Sunderland, Massachussets, USA.

Bolhar-Nordenkampf, H.R., and G. Oquist 1993. Chlorophyll fluorescence as a tool in photosynthesis research. Pages 193-206. In: D.O. Hall, J.M.O. Scurlock, H.R. Bolhar-Nordenkampf, R.C. Leegood, and S.P. Long (eds.). Photosynthesis and Production in a Changing Environment: a Field and Laboratory Manual. Chapman and Hall, London, UK..

Close, D.C. and C.L. Beadle 2003. Chilling-dependent photoinhibition, nutrition and growth analysis of Eucalyptus nitens seedlings during establishment. Tree Physiology. 23:217-226.

Conroy, J.P., P.J. Milham, M.L. Reed, and E.W. Barlow 1990. Increases in phosphorus requirements for $\mathrm{CO}_{2}$-enriched Pine species. Plant Physiology 92:977-982.

Conroy, J.P., R.M. Smillie, M. Kuppers, D.I. Bevege, and E.W. Barlow 1986. Chlorophyll a fluorescence and photosynthetic and growth responses of Pinus radiata to phosphorus deficiency, drought stress, and high $\mathrm{CO}_{2}$. Plant Physiology. 81:423-429.

Cookson, S.J., M. Van Lijsebettens, and C. Granier 2005. Correlation between leaf growth variables suggest intrinsic and early controls of leaf size in Arabidopsis thaliana. Plant Cell and Environment 28:1355-1366.

Demmig-Adams, B., W.W. Adams III, B.A. Logan, and A.S. Verhoeven 1995. Xantophyll cycledependent energy dissipation and flexible photosystem II efficiency in plants acclimated to light stress. Australian Journal Plant Physiology 22:249-260.

Fife, D.N., and E.K.S. Nambiar 1997. Changes in the canopy and growth of Pinus radiata in response to nitrogen supply. Forest Ecology and Management 93:137-152.

Genty, B., J. Briantais, and N.R. Baker 1989. The relationship between the quantum yield of photosynthetic electron transport and quenching of chlorophyll fluorescence. Biochimica et Biophysica Acta 990:87-92.

Gough, C.M., J.R. Seiler, and C.A. Maier 2004. Short-term effects of fertilization on loblolly pine (Pinus taeda L.) physiology. Plant Cell and Environment 27:876-886.

Greer, D.H. 1995. Effect of canopy position on the susceptibility of kiwifruit (Actinidia deliciosa) leaves on vines in an orchard environment to photoinhibition throughout the growing season. Australian Journal Plant Physiology 22:299309.

Guo, D.P., Y.P. Guo, J.P. Zhao, H. Liu, Y. Peng, Q.M. Wang, J.S. Chen, and G.Z. Rao 2005. Photosynthetic rate and chlorophyll fluorescence in leaves of stem mustard (Brassica juncea var. tsaitsai) after turnip mosaic virus infection. Plant Science 168:57-63.

Ingestad, T. 1971. A definition of optimum nutrient requirements in Birch Seedlings. II. Physiologia Plantarum 24:118-125.

Ingestad, T. 1979. Mineral nutrient requirements of Pinus silvestris and Picea abies seedlings. Physiologia Plantarum 45:373-380.

Ingestad, T. and A. Lund 1986. New concepts on soil fertility and plant nutrition as illustrated by research on forest trees and stands. Geoderma. 40:237-252.

Knecht, M.F., and A. Goransonn 2004. Terrestrial plants require nutrients in similar proportions. Tree physiology 24:447-460.

Koehn, A.C., J.H. Roberds, and R.L. Doudrick 2003. Variation among slash pine families in chlorophyll fluorescence traits. Canadian Journal of Forest Research 33:1102-1109.

Krause, G.H., and E. Weis 1991. Chlorophyll fluo- 
rescence and photosynthesis: The basics. Annual Review of Plant Physiology and Plant Molecular Biology 42:313-349.

Lavigne, M.B., C.H.A. Little, and J.E. Major 2001. Increasing the sink:source balance enhances photosynthetic rate of 1-year-old balsam fir foliage by increasing allocation of mineral nutrients. Tree Physiology 21:417-426.

Lewis, N.B. and I.S. Ferguson 1993. Management of Radiata Pine. Inkata Press, Melbourne. 404 p.

Loustau, D., M. Brahim, J.P. Gaudillere, and E. Dreyer 1999. Photosynthetic responses to phosphorus nutrition in two-year-old maritime pine seedlings. Tree Physiology 19:707-715.

Marschner, H. 1995. Mineral nutrition of higher plants. Academic Press, London. xv, 889 pp.

Marshall, J.D., G.E. Rehfeldt, and R.A. Monserud 2001. Family differences in height growth and photosynthetic traits in three conifers. Tree Physiology 21:727-734.

Maxwell, K., and G.N. Johnson 2000. Chlorophyll fluorescence - a practical guide. Journal of Experimental Botany 51:659-668.

Menzies, M.I., D.G. Holden, and B.K. Klomp 2001. Recent trends in nursery practice in New Zealand. New Forests 22:3-17.

Niinemets, U., D.S. Ellsworth, A. Lukjanova, and M. Tobias 2001. Site fertility and the morphological and photosynthetic acclimation of Pinus sylvestris needles to light. Tree Physiology 21:12311244.

Pearcy, R.W., O. Bjorkman, M.M. Caldwell, J.E. Keeley, R.K. Monson, and B.R. Strain 1987. Carbon gain by plants in natural environments: carbon assimilation analysis provides an understanding of how plants function in diverse environments. Bioscience 37:21-29.

Prioul, J.L., and P. Chartier 1977. Partitioning of transfer and carboxilation components of intracellular resistance to photosynthesis $\mathrm{CO}_{2}$ fixation: a critical analysis of the methods used. Ann. Bot. 41:789-800.

Puertolas, J., L. Gil, and J.A. Pardos 2005. Effects of nitrogen fertilization and temperature on frost hardiness of Aleppo pine (Pinus halepensis Mill.) seedlings assessed by chlorophyll fluorescence. Forestry 78:501-511.

Rascher, U., M. Liebig, and U. Luttge 2000. Evaluation of instant light-response curves of chlo- rophyll fluorescence parameters obtained with a portable chlorophyll fluorometer on site in the field. Plant Cell and Environment 23:13971405.

Reich, P.B., and A.W. Schoettle 1988. Role of phosphorus and nitrogen in photosynthetic and whole plant carbon gain and nutrient use efficiency in eastern white pine. Oecologia 77:25-33.

Rosenqvist, E., and O. van Kooten 2003. Chlorophyll fluorescence: a general description and nomenclature.Pages 30-77. In J.R. DeEll and P.M.A. Toivonen (eds.). Practical Applications of Chlorophyll Fluorescence in Plant Biology. Kluwer Academic Publishers, Norwell, Massachusetts,USA.

Ruban, A.V., and P. Horton 1995. Regulation of nonphotochemical quenching of chlorophyll fluorescence in plants. Australian Journal Plant Physiology 22:221-230.

Schreiber, U., W. Bilger, and C. Neubauer. 1994. Chrorophyll fluorescence as a nonintrusive indicator for rapid assessment of in vivo photosynthesis. Pages 49-70. In E.D. Schulze and M.M. Caldwell (eds.). Ecophysiology of Photosynthesis.. Springer Verlag, Berlin, Germany.

Seibert, M. 1995. Reflections on the nature and function of the photosystem II reaction centre. Australian Journal Plant Physiology 22:161-166.

Turnbull, M.H., D.T. Tissue, K.L. Griffin, G.N.D. Rogers, and D. Whitehead 1998. Photosynthetic acclimation to long-term exposure to elevated $\mathrm{CO}_{2}$ concentration in Pinus radiata D.Don is related to age of needles. Plant Cell and Environment. 21:1019-1028.

von Caemmerer, S. 2000. Biochemical models of leaf photosynthesis. CSIRO Publishing, Collingwood,Victoria, Australia. $165 \mathrm{p}$.

Watt, M.S., G. Coker, P.W. Clinton, M.R. Davis, R. Parfitt, R. Simcock, L. Garret, T.W. Payn, B. Richardson, and A. Dunningham 2005. Defining sustainability of plantation forests through identification of site quality indicators influencing productivity- a national view for New Zealand. Forest Ecology and Management 216:51-63.

Will, G.M. 1985. Nutrient deficiencies and fertiliser use in New Zealand exotic forests. Forest Research Institute Bulletin No 97, Rotorua, New Zealand, p. 53. 